\title{
Kajian Variasi Lama Perendaman Dalam Larutan Natrium Metabisulfit (Na2S205) Terhadap Kualitas Tepung Pisang Kepok (Musa Paradisiaca)
}

\author{
(Study Of Variation During The Immersion In Sodium Metabisulfit Solution (Na2s2o5) On \\ Quality Of Flour Banana Kepok (Musa Paradisiaca))
}

\author{
Ade Rika Marsita ${ }^{1}$, Ratna ${ }^{1}$, Bambang Sukarno Putra ${ }^{{ }^{*}}$ \\ ${ }^{1}$ Program Studi Teknik Pertanian Fakultas Pertanian Universitas Syiah Kuala \\ *Corresponding author: bambangtp@unsyiah.ac.id
}

\begin{abstract}
Abstrak Pisang merupakan buah yang sering dikonsumsi oleh masyarakat dibandingkan dengan buah yang lain. Buah pisang memiliki kandungan gizi yang tinggi, diantaranya mengandung vitamin $\mathrm{C}$, vitamin $\mathrm{B}$, sejumlah serat dan berbagai mineral yang penting untuk tubuh. Penelitian ini Penelitian ini bertujuan untuk mengetahui pengaruh larutan natrium metabisulfit $3000 \mathrm{ppm}$ terhadap variasi lama perendaman terhadap kualitas tepung pisang kepok. Penelitian ini menggunakan Rancangan Acak Lengkap (RAL) non faktorial dengan variasi lama perendaman 0, 20, 40, dan 60 menit. Parameter penelitian meliputi rendemen, kadar air, kadar pati, derajat keasaman $(\mathrm{pH})$, uji hedonik warna, aroma dan rasa. Hasil penelitian kajian variasi lama perendaman dalam larutan natrium metabisulfit pada pengolahan tepung pisang kepok terhadap rendemen berkisar antara 12,12\%-12,63\%, kadar air berkisar antara 6,28\%-6,96\%, kadar pati pisang berkisar antara 22,52\%-25,96\%, pH berkisar antara 6,20-6,40, uji organoleptik warna berkisar antara 3,87-4,4, aroma berkisar antara 2,67-3,73, dan rasa berkisar antara 3,43-3,71. Berdasarkan analisis sidik ragam lama perendaman dalam larutan natrium metabisulfit 3000 ppm berpengaruh nyata terhadap uji kesukaan hedonik warna dengan skor tertinggi 4 (suka) pada lama perendaman 60 menit, dan berpengaruh nyata terhadap uji organoleptik hedonik aroma dengan skor tertinggi 3 (netral) pada perendaman 0 menit. Namun lama perendaman dalam larutan natrium metabisulfit $3000 \mathrm{ppm}$ berpengaruh tidak nyata terhadap rendemen, kadar air, kadar pati, derajat keasaman, dan uji hedonik rasa. Berdasarkan hasil uji lanjut BNT dapat disimpulkan bahwa perlakuan terbaik terdapat pada lama perendaman 20 menit mendapatkan penilaian organoleptik pada warna dengan skor 4,23 dan aroma dengan skor 3,57 serta pada rasa dengan skor 3,67. Pada perendaman 20 menit ini didapatkan hasil rendemen dengan persentasi $12,50 \%$ dan kadar air 6,41 \% serta didapatkan kadar pati sebesar 22,85 \%, adapun derajat keasaman yang didapat 6,31 .
\end{abstract}

Kata Kunci : Pisang Kepok, lama perendaman, natrium metabisulfit, dan tepung pisang kepok.

Abstract Banana is a fruit that is often consumed by the public compared to other fruits. Banana fruit has a high nutritional content, including vitamin $\mathrm{C}$, vitamin $\mathrm{B}$, a number of fiber and various minerals that are important for the body. This study aims to determine the effect of $3000 \mathrm{ppm}$ sodium metabisulfite solution on variations in soaking time on the quality of Kepok banana flour. This study uses a non factorial Complete Randomized Design (RAL) with variations of immersion time 0, 20, 40, and 60 minutes. Research parameters include yield, water content, starch content, acidity $(\mathrm{pH})$, hedonic test of color, aroma and taste. The results of research studies the variation of immersion time in sodium metabisulfite solution in the processing of Kepok banana flour to yields ranged from $12.12 \%-12.63 \%$, water content ranged from $6.28 \%-6.96 \%$, banana starch levels ranged between $22,52 \%-25.96 \%$, $\mathrm{pH}$ ranged from 6.20 to 6.40 , organoleptic test colors ranged from $3.87-4.4$, aromas ranged from 2.67 to 3.73 , and flavors ranged from $3.43-3.71$. Based on the analysis of various immersion length immersion in sodium metabisulfite solution $3000 \mathrm{ppm}$ significantly affected the color hedonic preference test with the highest score of 4 (likes) on the 60 minute immersion time, and significantly affected the organoleptic aroma hedonic test with the highest score of 3 (neutral) on immersion 0 minute. However, soaking time in $3000 \mathrm{ppm}$ sodium metabisulfite solution did not significantly affect yield, water content, starch content, acidity, and taste hedonic test. Based on the results of BNT further tests, it can be concluded that the best treatment found in the 20 minute soaking time received organoleptic assessment of color with a score of 4.23 and aroma with a score of 3.57 and on taste with a score of 3.67 . In this 20 minute immersion, the yield yield was $12.50 \%$ and the water content was $6.41 \%$ and the starch content was $22.85 \%$, while the degree of acidity was 6.31 .

Keywords: Kepok Banana, soaking time, sodium metabisulfite, and Kepok banana flour. 


\section{PENDAHULUAN}

Pisang merupakan buah yang sering dikonsumsi oleh masyarakat dibandingkan dengan buah yang lain. Buah pisang memiliki kandungan gizi yang tinggi, diantaranya mengandung vitamin $\mathrm{C}$, vitamin $\mathrm{B}$, sejumlah serat dan berbagai mineral yang penting untuk tubuh. Bukan hanya buah pisang yang memiliki kandungan gizi yang tinggi, namun bagian lain dari pohon pisang yaitu kulit pisang juga mengandung gizi tinggi. Pisang memiliki kulit yang sangat tebal dengan warna kuning kehijauan dan kadang bernoda cokelat, serta daging buahnya manis. Pada buah pisang yang tidak mungkin disajikan sebagai buah segar karena alasan seperti ukuran buah kecil atau kulit buah cacat, dengan biaya yang rendah memiliki potensial diproduksi menjadi tepung pisang. Upaya pemanfaatan buah pisang yang masih mentah dan mengolahnya menjadi tepung untuk dijadikan beragam produk inovatif seperti cookies tahan cerna dalam meningkatkan kegunaan buah pisang (Aparicio-Saguilan et al., 2007).

Dalam pengolahan tepung pisang kepok ditemukan masalah pada proses pengupasan dan pengirisan, dimana pada proses ini pisang kepok akan mengalami pencoklatan (browning) sehingga mempengaruhi mutu tepung pisang kepok yang akan dihasilkan. Sebelumnya sudah ada penelitian Kurniawan (2009) mengenai proses pembuatan tepung pisang kepok dengan variasi lama perendaman menggunakan asam sitrat. Oleh karena itu perlu dilakukan penelitian tentang bagaimana pengaruh lama perendaman pisang kepok dalam larutan natrium metabisulfit $\left(\mathrm{Na}_{2} \mathrm{~S}_{2} \mathrm{O}_{5}\right)$ terhadap pengolahan tepung pisang kepok.

Tepung pisang salah satu olahan pisang yang bertujuan untuk pengawetan pisang dalam bentuk olahan. Syarat bahan pembuatan tepung pisang adalah buah pisang mentah yang sudah tua, tetapi belum masak. Keunggulan dari pengolahan pisang menjadi tepung pisang adalah meningkatkan daya guna, hasil guna, dan nilai guna, lebih mudah diolah atau diproses menjadi produk yang memiliki nilai ekonomi tinggi, lebih mudah dicampur dengan tepung dan bahan lainnya, serta menambah umur simpan pisang sendiri.

\section{METODE PENELITIAN}

\section{Waktu dan Tempat}

Kegiatan penelitian ini dilaksanakan pada bulan Juni sampai Juli 2019 di Laboratorium Teknik Pasca Panen, Program Studi Teknik Pertanian, Fakultas Pertanian, Universitas Syiah Kuala, Darussalam, Banda Aceh, serta Laboratorium Analisis Hasil Pangan, Program Studi Teknologi Hasil Pertanian, Fakultas Pertanian, Universitas SyIah Kuala, Darussalam, Banda aceh.

\section{Alat dan Bahan}

Alat yang digunakan pada penelitian ini adalah pisau, telenan, baskom, grinder, alat pengering tipe tray dryer, timbangan analitik, benchtop pH meret merek AZ 86505, cawan petri, ayakan 60 mesh, dan gelas ukur. Bahan yang digunakan dalam penelitian ini adalah buah pisang yang diperoleh dari kawasan Kota Banda Aceh, bubuk $\mathrm{Na}_{2} \mathrm{~S}_{2} \mathrm{O}_{5}$ dan aquades. 


\section{Prosedur Penelitian}

Tahapan pertama adalah pengadaan pisang yang tua, pisang dilepas dari sisirnya. Kemudian dikupas kulitnya menggunakan pisau dan juga dicuci dengam air bersih. Pisang yang telah dikupas kulitnya selanjutnya diiris tipis-tipis melintang, dan di timbang sebanyak 500 g tiap-tiap perlakuan. Setelah ditimbang kemudian direndam menggunakan larutan $\mathrm{Na}_{2} \mathrm{~S}_{2} \mathrm{O}_{5}$ dengan konsentrasi 3000 ppm, dimana dilakukan perlakuan lama perendaman dengan variasi 0, 20, 40 dan 60 menit. Proses pembuatan larutan dilakukan dengan cara menimbang 3 g natrium metabisulfit kemudian dimasukkan ke dalam tabung reaksi lalu ditambahkan dengan aquades hingga mencapai garis $1.000 \mathrm{ml}$ pada tabung reaksi, selanjutnya natrium metabisulfit yang telah dicampur dengan air diaduk hingga homogen. Selanjutnya dilakukan pengeringan dengan alat pengering tipe tray dryer pada suhu $45^{\circ} \mathrm{C}$ sampai kadar air mencapai $12 \%$. Setelah kering pisang digiling dengan menggunakan grinder dan diayak menggunakan ayakan 60 mesh.

\section{HASIL DAN PEMBAHASAN}

\section{Rendemen Tepung Pisang Kepok}

Rendemen tepung pisang kepok berdasarkan variasi lama perendaman dalam larutan natrium metabisulfit 3000 ppm dapat dilihat pada Gambar dibawah ini

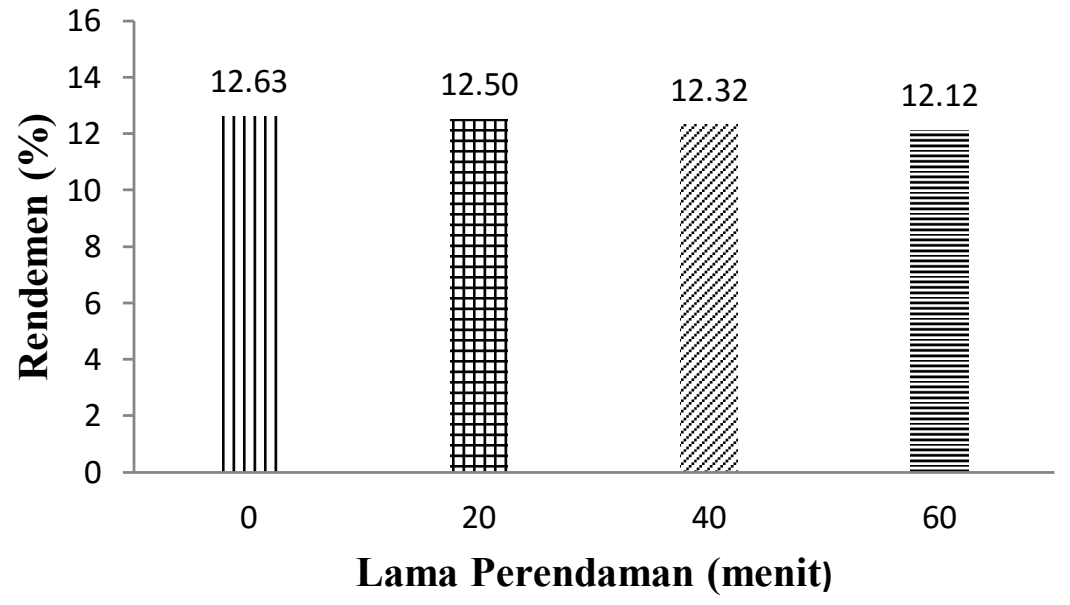

Gambar 1. Rendemen Tepung Pisang Kepok Berdasarkan Variasi Lama Perendaman

Berdasarkan Gambar diatas dapat dilihat bahwa rendemen tertinggi terdapat pada perlakuan tanpa perendaman sebesar $12,63 \%$ dan rendemen terendah didapatkan pada lama perendaman 60 menit sebesar 12,12\%. Dari analisis sidik ragam terdapat rendemen (Lampiran 9) menunjukkan bahwa variasi lama perendaman dengan larutan natrium metabisulfit 3000 ppm tidak berpengaruh nyata $(p>0,05)$ terhadap rendemen tepung pisang kepok. Rendahnya rendemen yang didapatkan juga disebabkan oleh tahapan dalam proses pembuatan tepung pada saat pengeringan.

Rendahnya rendemen yang didapatkan juga disebabkan oleh tahapan dalam proses pembuatan tepung pada saat pengeringan. Semakin rendah suhu yang digunakan maka 
semakin sedikit air yang teruapkan sehingga diperoleh rendemen yang tinggi. Perbedaan tinggi rendahnya rendemen suatu bahan pangan sangat dipengaruhi oleh kandungan air suatu bahan pangan seperti yang dinyatakan Martunis (2012).

\section{Kadar Air Tepung Pisang Kepok}

Kadar air tepung pisang kepok berdasarkan variasi lama perendaman dalam larutan natrium metabisulfit 3000 ppm dapat dilihat pada gambar dibawah ini

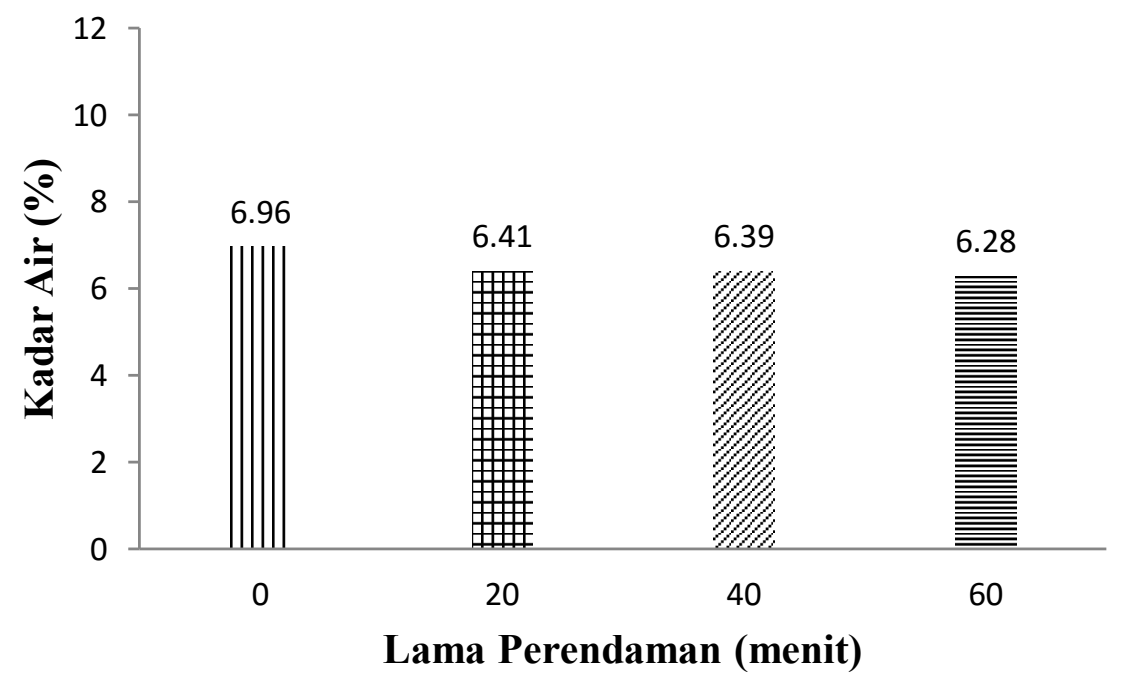

Gambar 2. Persentase Kadar Air Tepung Pisang Kepok Berdasarkan Variasi Lama Perendaman

Berdasarkan Gambar diatas dapat dilihat bahwa kadar air tertinggi terdapat pada perlakuan tanpa perendaman sebesar $6,96 \%$ dan kadar air terendah terdapat pada lama perendaman 6,28 \%. Dari analisis sidik ragam yang terdapat pada (Lampiran 10) menunjukkan bahwa variasi lama perendaman dengan larutan natrium metabisulfit 3000 ppm tidak berpengaruh nyata $(\mathrm{p}>0,05)$ terhadap kadar air tepung pisang kepok sehingga tidak dilakukannya uji lanjut. Kadar air pada tepung sangat berpengaruh besar terhadap mutu dan memperpanjang masa simpan dari tepung tersebut. Sesuai dengan pernyataan Gunawan (2016) penentuan kadar air dari suatu bahan pangan sangat penting agar memudahkan dalam proses pengolahan maupun pendistribusinya. Penelitian Khathir dkk (2010) pada pengeringan tepung beras mendapatkan kadar air tidak jauh berbeda dengan tepung pisang yaitu sekitar 9,18 \% dan memenuhi kadar air sesuai standar SNI. Semakin lama proses pengeringan maka semakin rendah kadar air tepung yang dihasilkan. Faktor utama yang mempengaruhi pengeringan yaitu kecepatan pengeringan dari suatu bahan pangan (Bukle, 1958). Selama pengeringan terjadi proses perpindahan panas adalah proses menguapkan air dari dalam bahan atau proses perpindahan bentuk air dari cair ke gas. Proses perpindahan massa yaitu suatu proses perpindahan massa uap air dari permukaan ke udara (winarno, 1997)

\section{Kadar Pati Tepung Pisang Kepok}


Kadar pati tepung pisang kepok berdasarkan variasi lama perendaman dalam larutan natrium metabisulfit 3000 ppm dapat dilihat pada Gambar dibawah ini

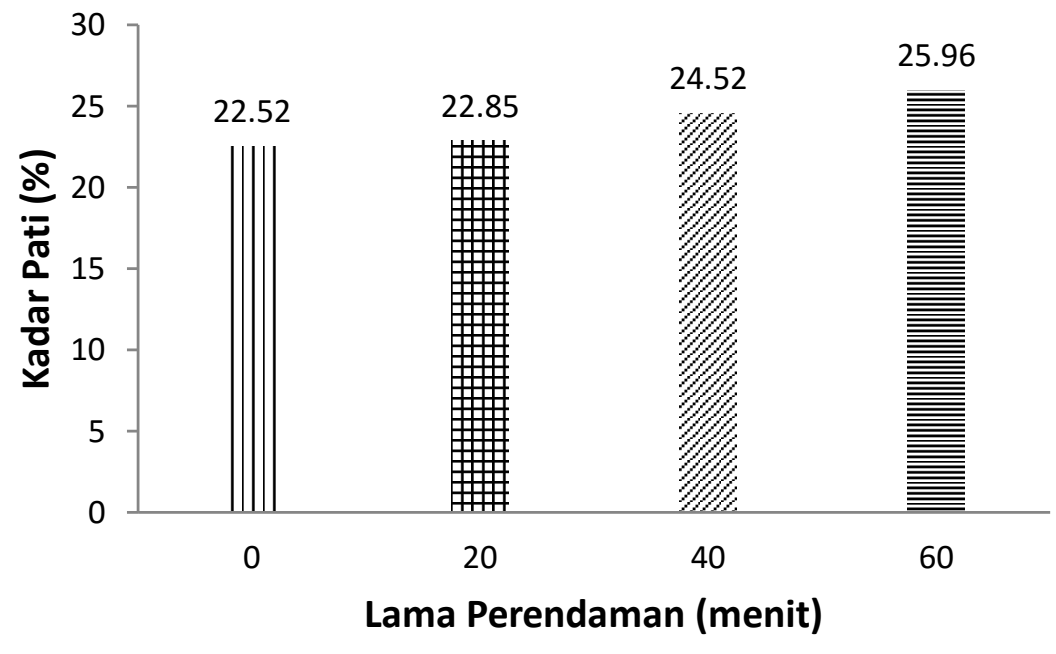

Gambar 2. Persentase Kadar Padi Tepung Pisang Kepok Berdasarkan Variasi Lama Perendaman

Berdasarkan gambar dibelakang kadar pati tertinggi terdapat pada perlakuan lama perendaman 60 menit sebesar 25,96\% dan kadar pati terendah terdapat diperendaman 0 menit yaitu sebesar 22,52 \%. Berdasarkan hasil analisis sidik ragam (Lampiran 11) menunjukkan bahwa variasi lama perendaman dengan larutan natrium metabisulfit 3000 ppm tidak berpengaruh nyata $(\mathrm{p}>0,05)$ terhadap kadar pati tepung pisang kepok.

Semakin lama perendaman maka kadar pati dari tepung pisang kepok semakin tinggi dikarenakan kandungan pati yang tinggi disebabkan oleh karakteristik pati yang tidak larut dalam air, sehingga perlakuan variasi lama perendaman tidak menyebabkan penurunan pati dimana menurut Andrawulan (2008) bahwa penurunan kadar cerna pati yaitu karena penggunaan suhu tinggi dan waktu pemanasan yang terlalu lama saat pengolahan.

\section{Derajat Keasaman (pH) Tepung Pisang Kepok}

Derajat keasaman $(\mathrm{pH})$ tepung pisang kepok berdasarkan variasi lama perendaman dalam larutan natrium metabisulfit 3000 ppm pada dilihat pada Gambar dibawah ini 


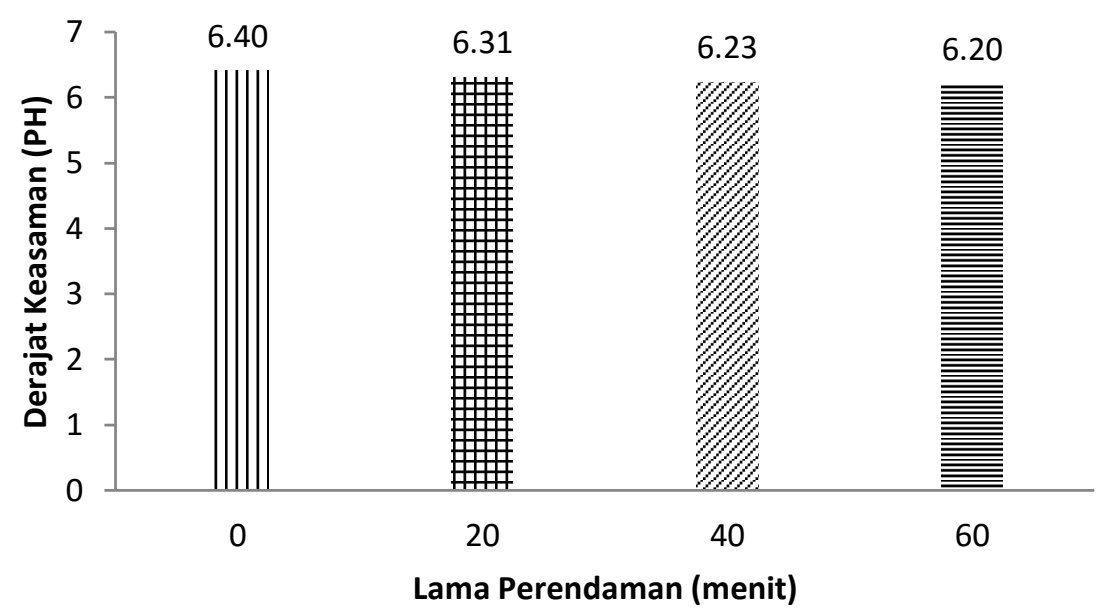

Gambar 3. Persentase Derajat Keasaman Tepung Pisang Kepok Berdasarkan Variasi Lama

Perendaman

Berdasarkan gambar diatas dapat dilihat bahwa derajat keasaman $(\mathrm{pH})$ yang terkandung pada tepung pisang kepok tertinggi terdapat pada lama perendaman 0 menit sebesar 6,40 sedangkan derajat keasaman $(\mathrm{pH})$ terendah terdapat pada lama perendaman 60 menit sebesar 6,20. Berdasarkan hasil sidik ragam terhadap $\mathrm{pH}$ yang terdapat pada (Lampiran 12) diketahui bahwa lama perendaman larutan natrium metabisulfit $3000 \mathrm{ppm}$ tidak berpengaruh nyata $(\mathrm{p}>0,05)$ terhadap derajat keasaman $(\mathrm{pH})$ tepung pisang kepok. Berdasarkan data pada gambar 6 dapat dilihat bahwa tepung pisang kepok dengan masingmasing perlakuan memperoleh nilai $\mathrm{pH}$ yang hampir sama. Hal ini terjadi karena natrium metabisulfit memiliki sifat terasa asam.

\section{Uji Organoleptik Terhadap Tepung Pisang Kepok}

Uji organoleptik yang dilakukan bertujuan untuk mengetahui penilaian panelis terhadap tepung pisang kepok yang dihasilkan.

\section{Warna}

Kesukaan terhadap warna tepung pisang kepok berdasarkan variasi lama perendaman dalam natrium metabisulfit 3000 ppm dapat dilihaat pada gambar dibawah ini 


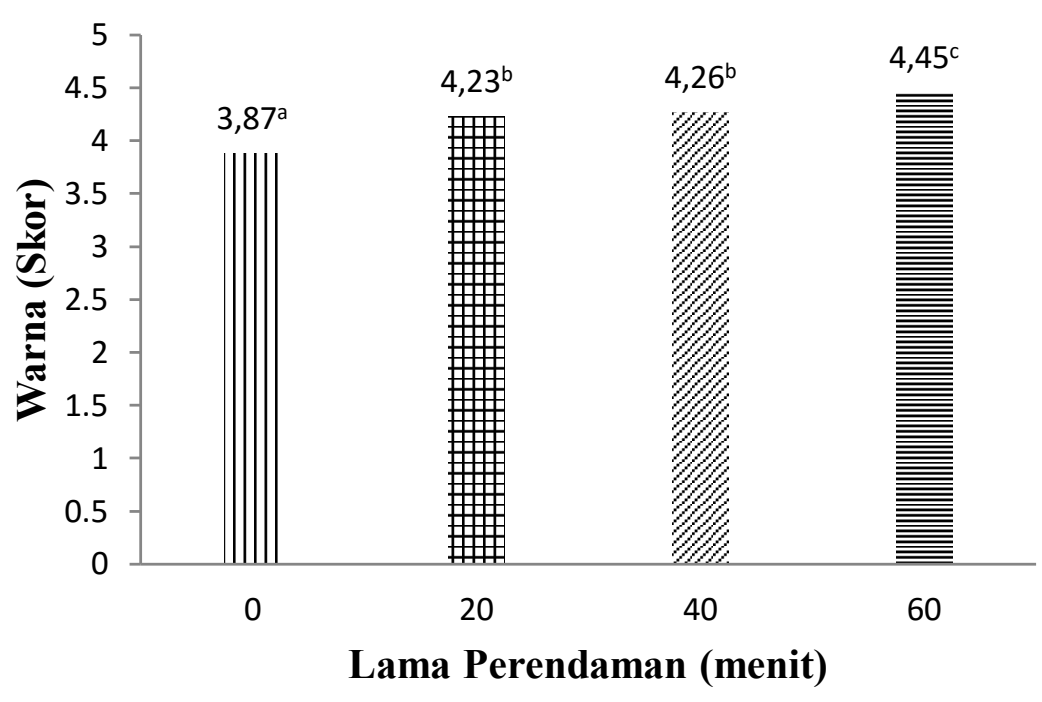

Gambar 3. Warna Tepung Pisang Kepok Berdasarkan Variasi Lama Perendaman

Berdasarkan hasil uji organoleptik hedonik pada gambar diatas dapat diketahui bahwa skor tertinggi pada lama perendaman 60 menit dengan skor 4 (suka) dan nilai terendah diperoleh pada perlakuan 0 menit dengan skor 3 (netral). Berdasarkan hasil analisis sidik ragam terdapat hedonik (lampiran 13) diketahui bahwa variasi lama perendaman larutan natrium metabisulfit berpengaruh sangat nyata $(\mathrm{p}<0,05)$ terhadap kesukaaan warna tepung pisang kepok, maka skor kesukaan warna tersebut kemudian diteruskan dengan uji lanjut BNT (LSD). Setelah dilakukan uji lanjut BNT terhadap skor kesukaan warna pisang kepok pada Gambar 8 dapat diketahui bahwa skor kesukaan terhadap warna pada perlakuan 0 menit berbeda nyata dengan perlakuan 20 menit, 40 menit dan 60 menit, namun perlakuan lama perendaman 20 menit tidak berbeda nyata dengan perlakuan lama perendaman 40 menit. Maka dapat disimpulkan bahwa perlakuan terbaik diperoleh dari variasi lama perendaman 60 menit dengan larutan natrium metabisulfit. Dari gambar diatas dapat kita lihat bahwa semakin lama perendaman dalam larutan natrium metabisulfit semakin disukai oleh panelis.

\section{Aroma}

Kesukaan terhadap aroma tepung pisang kepok berdasarkan variasi lama perendaman dalam larutan natrium metabisulfit 3000 ppm Gambar dibawah ini 


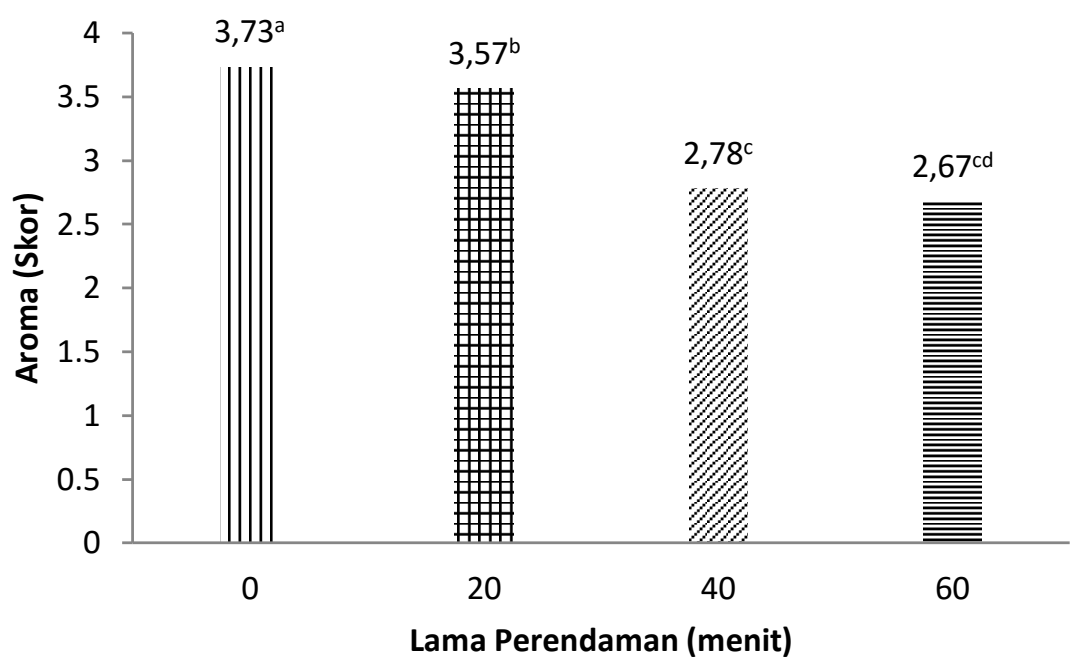

Gambar 3. Aroma Tepung Pisang Kepok Berdasarkan Variasi Lama Perendaman

Berdasarkan hasil uji organoleptik hedonik aroma pada Gambar diatas maka diketahui bahwa perlakuan tanpa perendaman dan perendaman 20 menit memiliki skor kesukaan 3 (netral) terhadap aroma tepung pisang kepok, sedangkan perlakuan lama perendaman 40 menit dan perendaman 60 menit memiliki skor 2 (tidak suka). Berdasarkan hasil analisis sidik ragam terhadap uji hedonik aroma (Lampiran 14) diketahui bahwa variasi lama perendaman larutan natrium metabisulfit berpengaruh sangat nyata $(\mathrm{p}<0,05)$ terhadap kesukaan aroma pada tepung pisang kepok, maka skor kesukaan warna tersebut kemudian diteruskan dengan uji lanjut BNT. Setelah dilakukan uji lanjut BNT terhadap skor kesukaan aroma pisang kepok pada Gambar 10 dapat diketahui bahwa skor kesukaan terhadap uji organoleptik hedonik aroma pada perlakuan 0 menit tidak berbeda nyata dengan perlakuan 20 menit, namun perlakuan 0 menit berbeda nyata dengan perlakuan lama perendaman 40 dan 60 menit. Serta perlakuan 40 menit tidak berbeda nyata terhadap 60 menit. Sehingga dapat disimpulkan bahwa perlakuan terbaik diperoleh pada lama perendaman 0 menit dalam larutan natrium metabisulfit.

\section{Rasa}

Kesukaan terhadap rasa tepung pisang kepok berdasarkan variasi lama perendaman dalam larutan natrium metabisulfit 3000 ppm dapat dilihat pada Gambar 11 


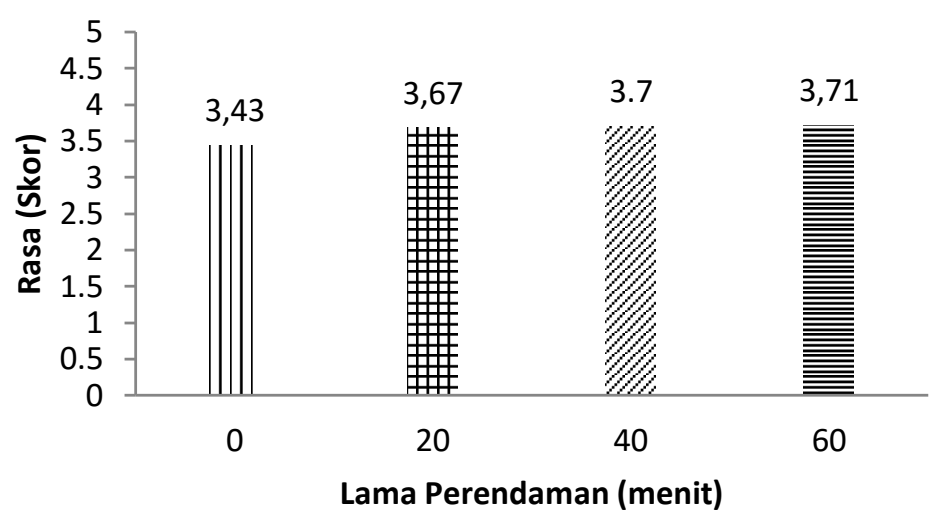

Gambar 3. RasaTepung Pisang Kepok Berdasarkan Variasi Lama Perendaman

Dari hasil uji organoleptik hedonik rasa diatas pada gambar dibelakang menunjukkan bahwa perlakuan tanpa perendaman 0 menit tidak berpengaruh nyata terhadap perlakuan lama perendaman 20, 40 dan 60 menit. Dari keempat perlakuan lama perendaman tersebut memiliki skor kesukaan 3 (netral) terhadap tepung pisang kepok. Berdasarkan hasil analisis sidik ragam terdapat uji hedonik rasa (Lampiran 15) diketahui bahwa variasi lama perendaman dalam larutan natrium metabisulfit tidak berpengaruh nyata $(p>0,05)$ terhadap kesukaan rasa pada tepung pisang kepok, maka dari itu tidak dilakukannya uji lanjut.

\section{Penerimaan Keseluruhan}

Hasil parameter pengamatan yang dilakukan untuk mendapatkan hasil rendemen, kadar air, kadar pati, derajat keasaman, uji organoleptik warna, aroma dan rasa dapat dilihat pada Tabel 4

Tabel 4. Penerimaan Keseluruhan dari Parameter Penelitian Tepung Pisang Kepok

\begin{tabular}{cccccccc}
\hline $\begin{array}{c}\text { Perlakuan } \\
\text { Lama } \\
\begin{array}{c}\text { Perendama } \\
\mathrm{n}(\text { Menit) }\end{array}\end{array}$ & $\begin{array}{c}\text { Rendeme } \\
\mathrm{n}(\%)\end{array}$ & $\begin{array}{c}\text { Kadar } \\
\text { Air }(\%)\end{array}$ & $\begin{array}{c}\text { Kadar Pati } \\
(\%)\end{array}$ & $\begin{array}{c}\text { Derajat } \\
\text { Keasama } \\
\mathrm{n}(\%)\end{array}$ & $\begin{array}{c}\text { Warna } \\
\text { (Skor) }\end{array}$ & $\begin{array}{c}\text { Aroma } \\
\text { (Skor) }\end{array}$ & $\begin{array}{c}\text { Rasa } \\
\text { (Skor) }\end{array}$ \\
\hline 0 & 12,63 & 6,96 & 22,52 & 6,40 & $3,87^{\mathrm{a}}$ & $3,73^{\mathrm{a}}$ & 3,43 \\
20 & 12,50 & 6,41 & 22,85 & 6,31 & $4,23^{\mathrm{ab}}$ & $3,57^{\mathrm{a}}$ & 3,67 \\
40 & 12,32 & 6,39 & 24,52 & 6,23 & $4,26^{\mathrm{c}}$ & $2,78^{\mathrm{b}}$ & 3,70 \\
60 & 12,12 & 6,28 & 25,96 & 6,20 & $4,45^{\mathrm{cd}}$ & $2,67^{\mathrm{b}}$ & 3,71 \\
\hline
\end{tabular}

Hasil dari penelitian menunjukkan bahwa variasi lama perendaman dalam larutan natrium metabisulfit 3000 ppm memberi pengaruh tidat nyata terhadap rendemen, kadar air, kadar pati, derajat keasaman $(\mathrm{pH})$ dan kesukaan terhadap rasa. Namun pengaruh variasi lama 
perendaman dalam larutan natrium metabisulfit $3000 \mathrm{ppm}$ memberi pengaruh sangat nyata terhadap kesukaaan warna dan kesukaan aroma. Berdasarkan Tabel 4 dapat kita lihat bahwa perlakuan terbaik terdapat pada lama perendaman 20 menit.

\section{KESIMPULAN DAN SARAN}

\section{Kesimpulan}

Berdasarkan hasil dari penelitian pembuatan tepung pisang kepok dengan variasi lama perendaman dalam larutan natrium metabisulfit 3000 ppm dapat diambil simpulan sebagais berikut :

1. variasi lama perendaman dalam larutan natrium metabisulfit $3000 \mathrm{ppm}$ memberi pengaruh tidak nyata terhadap rendemen, kadar air, kadar pati, derajat keasaman $(\mathrm{pH})$ dan kesukaan terhadap rasa. Namun pengaruh variasi lama perendaman dalam larutan natrium metabisulfit 3000 ppm memberi pengaruh sangat nyata terhadap kesukaaan warna dan kesukaan aroma

2. Perlakuan terbaik terdapat pada lama perendaman 60 menit, dikarenakan pada perendaman 20 menit mendapatkan penilaian organoleptik pada warna dengan skor 4,23 dan aroma dengan skor 3,57 serta pada rasa dengan skor 3,67. Pada perendaman 20 menit ini didapatkan hasil rendemen dengan persentasi $12,50 \%$ dan kadar air 6,41\% serta didapatkan kadar pati sebesar $22,85 \%$, adapun derajat keasaman yang didapat 6,31 .

\section{Saran}

Adapun saran yang dapat diberikan demi mendapatkan tepung pisang kepok yang lebih baik perlu dilakukannya penelitian lanjutan dengan menguji kadar protein, kadar abu, lemak dan Vitamin C.

\section{DAFTAR PUSTAKA}

Andrawulan, N. 2008. Nilai Kalori Pangan Sumber Karbohidrat. Food Review Indonesia, Jakarta.

Aparicio-Saguilan, A., Sayago-Ayerdi, G. Sonia, Vargas-Torres, Apolonio, T. Juscelino, Ascencio-Otero, Tania, E. Andllo-Perez, Luis, A. 2007. Slowly digestible cookies prepared from resistant starch-rich litnerized banana starch. Journal of Food Composition and Analysis, 20:175-181.

Bukle, K.A. 1985. Ilmu Pangan. UI-Press, Jakarta

Gunawan, T. P. 2016. Kajian variasi lama perendaman dalam larutan kalsium hidroksida pada pembuatan tepung ubi jalar ungu. Skripsi. Fakultas Pertanian. Universitas Syiah Kuala, Banda Aceh.

Khathir R., Ratna Dan Wardani. 2011. Karakteristik Pengeringan Tepung Beras Menggunakan Alat Pengering Tipe Rak. Jurnal Ilmiah Pendidikan Biologi Universitas Syiah Kuala, Banda Aceh. 3(2) :1-4.

Martunis. 2012. Pengaruh Suhu Dan Lama Pemgeringan Terhadap Kuantitas Dan Kualitas Pati Kentang Varietas Granola. Jurnal Teknologi dan Industri Pertanian Indonesia. 4 (3) : 26-30.

Winarno, F. G. 1997. Kimia Pangan, dan Gizi. PT. Gramedia Pustaka Utama, Jakarta. 